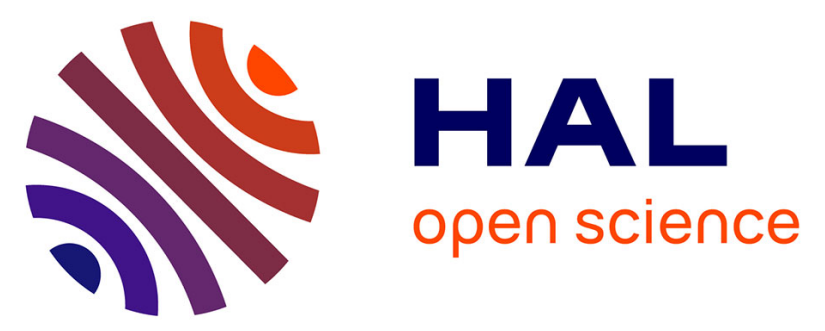

\title{
Evaluating sampling methods in charcoal-rich layers and high diversity environment: a case study from the Later Stone Age of Bushman Rock Shelter, South Africa
} Elysandre Puech, Marion Bamford, Guillaume E Porraz, Aurore Val, Isabelle Théry-Parisot

\section{To cite this version:}

Elysandre Puech, Marion Bamford, Guillaume E Porraz, Aurore Val, Isabelle Théry-Parisot. Evaluating sampling methods in charcoal-rich layers and high diversity environment: a case study from the Later Stone Age of Bushman Rock Shelter, South Africa. Quaternary International, 2020, 10.1016/j.quaint.2020.11.018 . hal-03034548

\author{
HAL Id: hal-03034548 \\ https://hal.science/hal-03034548
}

Submitted on 1 Dec 2020

HAL is a multi-disciplinary open access archive for the deposit and dissemination of scientific research documents, whether they are published or not. The documents may come from teaching and research institutions in France or abroad, or from public or private research centers.
L'archive ouverte pluridisciplinaire HAL, est destinée au dépôt et à la diffusion de documents scientifiques de niveau recherche, publiés ou non, émanant des établissements d'enseignement et de recherche français ou étrangers, des laboratoires publics ou privés. 


\title{
Quaternary International
}

Evaluating sampling methods in charcoal-rich layers and high diversity environment: a case study from the Later Stone Age of Bushman Rock Shelter, South Africa.

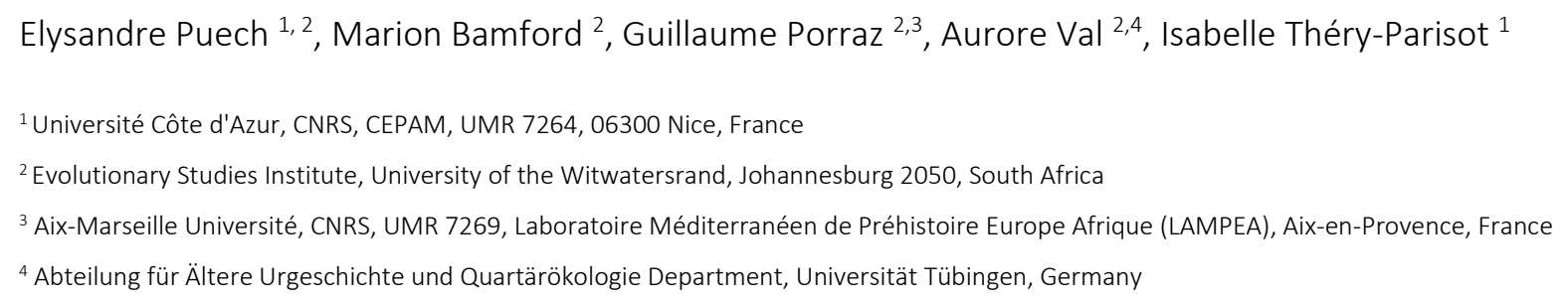

Keywords: Anthracology; Southern Africa; Sampling strategy; Sampling bias; Sample representativeness; Environmental representativeness; Temporal and spatial resolution; Species richness; Species diversity; Fragment size distribution.

\begin{abstract}
In southern Africa, archaeobotanical studies are intrinsically linked to prehistoric investigation and the discipline of anthracology has already proved its potential for palaeoenvironmental and palaeoecological reconstructions. While the region benefits from particularly good preservation of macro charcoal remains in its sites, anthracological studies remain underexplored and the methodological framework still needs to be developed and adapted to the diverse southern African ecological contexts. Here we provide a review of sampling methods and sample representativeness and we compare it with wood charcoal analyses performed in southern Africa. We used the charcoal-rich layers from the Later Stone Age sequence of Bushman Rock Shelter (BRS) to elaborate a sampling strategy producing samples that can both be analysed in a timely manner and that are statistically representative of the whole assemblage. In light of our results, we discuss the relevance of applying anthracological methods developed in European contexts. The evaluation of the taxa richness, diversity and size distribution at BRS leads to the recommendation of the identification of at least 500 charcoal fragments per stratigraphic unit. Thick layers should be split into two distinct samples, one comprising the top half and the other one the bottom half of the layer. The analysis of thin layers with limited charcoal abundance necessitates increasing the surface of sampling. All size-classes should be analysed to avoid any sampling bias.
\end{abstract}




\section{Introduction}

The potential of charcoals as palaeoenvironmental proxy is now widely acknowledged (e.g. Chabal, 1992; 1997; Figueiral and Mosbrugger, 2000). Scattered charcoals from secondary deposits, i.e. long-term and "synthetic" deposits (sensu Théry-Parisot et al., 2010a) are traditionally preferred for the investigation of past woody vegetation since a higher diversity of taxa tends to be represented and thus better reflects the local environment (Chabal, 1992; Asouti and Austin, 2005). However, charcoal assemblages from other types of deposits, such as fireplaces, still provide both environmental and cultural information as long as the modality and context of accumulations are considered and with the adoption of a strict sampling and quantification method (Asouti and Austin, 2005; Théry-Parisot et al., 2010a; Delhon, 2016).

To assess the use of charcoal fragments as a tool for palaeoenvironmental reconstruction, several anthracological studies have investigated the question of the optimal number of samples and fragments that should be analysed to provide statistically significant results (e.g. Chabal, 1997; Scheel-Ybert, 1998; Chabal et al., 1999; Asouti and Austin, 2005). Saturation curves estimating the species richness of a given assemblage are used primarily to ensure that the required minimal number of charcoal fragments is analysed (Chabal, 1997). This minimum number of fragments is attained when a clear stabilisation level is reached, defining a "saturation point". This saturation point ensures that the species richness of the whole assemblage is well represented in the sub-sample analysed.

In synthetic deposits, the species richness of the assemblage is considered to be similar to the species richness of the local environment and thus, the saturation point also ensures the ecological representativeness. However, palaeobotanical studies in high species diversity areas like in the tropics have shown that it is often difficult to obtain this stabilisation level (ScheelYbert, 1998; 2002). The use of Gini-Lorenz concentration curves that provide the woody plant diversity index (or Pareto index) were therefore developed to be compared with indices of modern ecological reference. Phytosociological studies show indices around 20:80 (i.e. 20\% of the species are represented in $80 \%$ of the analysed fragments) in temperate regions and between 30:70 and 25:75 in Brazilian tropical regions (Chabal et al., 1999; Scheel-Ybert, 2002). The combination of both curves to verify the minimum number of analysed charcoal fragments was first applied to archaeological charcoals from Mediterranean and temperate climatic 
conditions (Chabal, 1997). In temperate and Mediterranean Europe, this method highlighted the identification of large enough assemblages and recommended a minimum of 400 fragments per stratigraphic unit (Chabal et al., 1999). This approach was consequently extended to tropical (Scheel-Ybert, 2002; Dotte-Sarout et al., 2015; Dotte-Sarout, 2017; Dussol et al., 2017), as well as arid and semi-arid regions (e.g. Australia, Whitau et al., 2017). For instance, Scheel-Ybert (2002) suggests that a minimum of 200 to 300 fragments per samples is necessary to give a representative image of the past vegetation in Brazilian context.

In southern Africa, the potential of archaeologically recovered charcoals as a tool to reconstruct past woody vegetation was first recognised at Boomplaas Cave in South Africa (Deacon et al., 1983; 1984; Scholtz, 1986). Since then, other anthracological analyses undertaken at Middle Stone Age (MSA), Later Stone Age (LSA) and Iron Age sites have confirmed their reliability for palaeoenvironmental studies (Prior and Price Williams, 1985; Dowson, 1988; Tusenius, 1989; February, 1992; Wadley et al., 1992; Esterhuysen and Mitchell, 1996; Cartwright and Parkington, 1997; Cowling et al., 1999; Parkington et al., 2000; Allott, 2006; Bamford, 2015; Bamford et al., 2016; Mvimi, 2019). While most of these studies have highlighted the potential impact of the nature of the deposits, the wood selection bias or the sampling effect on the interpretation of the anthracological results, they were not supported by experimental investigation. The anthracological studies from Holocene sites of the Northern Namibian Desert (Eichhorn, 2002; 2007; Vogelsang et al., 2002; Vogelsang and Eichhorn, 2011) used a sampling strategy based on the method used in West African savannas (Neumann, 1999), itself derived from statistical studies from European environmental context (Chabal, 1992; Figueiral, 1992). Sample sizes of 200 to 400 fragments were considered representative for most of the sites and sometimes down to 150 fragments for semi-arid sites (Vogelsang and Eichhorn, 2011).

Except for Namibian anthracology studies, the representativeness of analysed samples and the choice of sampling methods have not been statistically investigated for southern African prehistoric contexts. For instance, Tusenius (1986) analysed between 22 and 78 charcoal fragments per layers from three different sites in the North Eastern Cape. February (1992) analysed charcoals from 12 sites from the KwaZulu-Natal and Limpopo Provinces with sample sizes varying from 20 to 390 fragments with fragment size ranges from 3 to $15 \mathrm{~mm}$. At Sibudu Cave, Allott (2006) analysed sub-samples of 120 fragments each from eight layers extracted from $2 \mathrm{~m}^{2}$ deposits in five size categories from 5 to $>20 \mathrm{~mm}$. Therefore, an intra- and inter-site 
variability of number and size of fragments analysed per units is generally observed. This seems to be the result of various interrelated factors such as the deposit contexts, the excavation techniques, the availability of reference materials and the challenge linked to taxa identification within the allocated time (Cartwright, 2015). The differential sampling protocols hinder the possibility to conduct meaningful statistical comparisons between sites. Furthermore, wood taxonomic identification is a time-consuming task, especially in the subtropical biomes of southern Africa, rich in plant species (Thuiller et al., 2006). In our study area, the southern African interior plateau in central Limpopo, the species and genera richness of the native woody plants (trees and shrubs of more than $2.5 \mathrm{~m}$ high) are estimated to include 479 species and 242 genera for a surface of $25000 \mathrm{~km}^{2}$ grid cell (for details see figures 2 and 3 in O'Brien et al., 1998).

At Bushman Rock Shelter (BRS here after), charcoals are the most common macro-botanical remains at the site, especially for the LSA sequence. A first diagnosis after dry sieving at $3 \mathrm{~mm}$ and sorting during excavation revealed high frequencies of charcoal fragments ranging up to $>20 \mathrm{~mm}$. The sequence benefits from a high stratigraphic resolution, well-dated occupations and preserves one of the few terrestrial archives of the late Pleistocene - early Holocene transition in southern Africa. The analysis of the rich-charcoal remains from BRS offers the opportunity to address questions regarding the economic as well as the ecological context in which the LSA hunter-gatherers evolved (Puech, 2019). Due to the abundant charcoal material, previous observations led to the investigation of a relevant sampling strategy to answer our research questions, while keeping the high resolution of the rich charcoal deposit. The purpose is to obtain manageable sample sizes and to assess whether the richness of the sample reflects the richness of the whole assemblage in order to avoid any bias that would be added to wood selection related to human choice or post-depositional factors. In future analyses of the charcoal material, this methodological investigation would allow us to obtain a more accurate image of the entire assemblage in order to discuss its representativeness regarding palaeoecological and palaeoeconomical interpretations (Théry-Parisot et al., 2010a; 2010b). To investigate which sub-sampling method is adequate and to ensure that it is reproducible, it is important to assess the influence of the fragment size-classes, the nature of sedimentary deposits and the spatial and temporal resolution on the charcoal spectra. We discuss the 
applicability of common European anthracological methods for sampling representativeness and their relevance to the southern African region.

\section{Environmental and archaeological context}

The archaeological site of BRS is located in the southeastern part of Limpopo Province (Ohrigstad District), near the border with Mpumalanga, about $300 \mathrm{~km}$ northeast of Johannesburg in South Africa (Porraz et al., 2015). Situated on the northern edge of the Great Escarpment in the Drakensberg chain, this south-facing shelter is carved within the dolomitic rocks of the Malmani Subgroup of the Transvaal Supergroup, with an average altitude of 950 meters above sea level. Modern landscape around the site straddles the Grassland and Savanna Biomes of the Highveld, to the west of the dramatic Blyde River Canyon, representing the physical and ecological limit with the Lowveld to the east (Figure 1). More locally, the Molapong and the Ohrigstad Rivers, tributaries of the Blyde River, flow close to the shelter. The current local vegetation is characterised by open to closed woodland, with well-developed shrub layers along the low mountain slope - "Poung Dolomite Mountain Bushveld" vegetation-type surrounded by a cultivated valley with higher elevation patches of woody grassland - "Ohrigstad Mountain Bushveld" and "Lydenburg Thornveld" vegetation-types (Mucina and Rutherford, 2006). Amongst the variety of plants surrounding the site, the following shrub and woody taxa are present: the marula (Sclerocarya birrea subsp. caffra), the stamvrug (Englerophytum magalismontanum), the jacket-plum (Pappea capensis), the African olive (Olea europea subsp. europea), several species of Acacia spp. (Vachellia spp. and Senegalia spp.), bushwillow (Combretum spp.), figs (Ficus spp.) and Grewia spp. (Porraz et al., 2015, and personal field observations). The site is located at the junction of two major centres of plant endemism, Sekhukhune Centre (Siebert et al., 2002) and Wolkberg Centre (Van Wyk and Smith, 2001). The local climate is controlled by a summer rainfall regime characterised by mild and dry winters with a mean annual precipitation of about $900 \mathrm{~mm}$ and a mean annual temperature of $17.7^{\circ} \mathrm{C}$ (Mucina and Rutherford, 2006). 


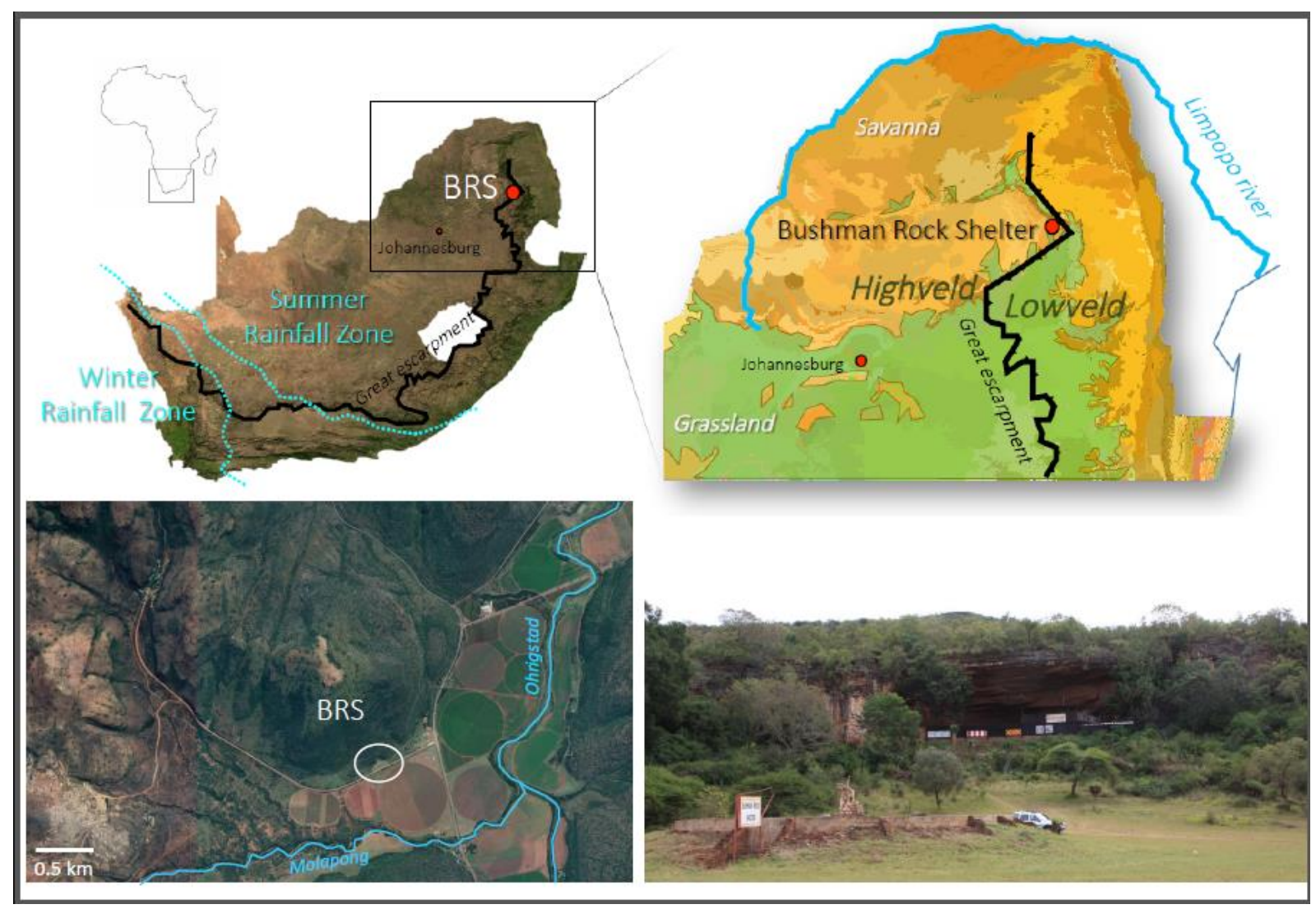

Figure 1: Location of Bushman Rock Shelter (BRS). Top left: map of South Africa with seasonal rainfall regimes and the Great escarpment. Top right: zoom on the Limpopo area with vegetation biomes (adapted from Mucina and Rutherford, 2006). Bottom left: aerial view of the site with major rivers. Bottom right: view of the south-facing shelter.

Excavations during the 1960's to 1970's exposed a well-stratified sequence of ca. $7 \mathrm{~m}$ thick deposits associated with ephemeral Iron Age occupations capping two extensive chronocultural phases attributed to the LSA and the MSA (Eloff, 1969; Louw, 1969; Plug, 1981). A new excavation was initiated in 2014 (Porraz et al., 2015) to investigate late Pleistocene and early Holocene cultural dynamics in the eastern part of the southern African interior plateau, a somewhat forgotten geographical area, to refine the palaeoenvironmental context at a local scale, and to place the sequence within the current southern African chrono-cultural archaeological framework (Lombard et al., 2012). The LSA sequence covers about $1.5 \mathrm{~m}$ thick deposits and benefits from a robust chronology with main two occupational phases covering the period dated to about 15.7-10.7 ka cal BP, consistent with the end of the Pleistocene and the onset of the Holocene (Figure 2). The evolution observed in the lithic and bone industries informs about the succession from the Robberg to the Oakhurst techno-complexes. The fauna comprises a majority of small to large bovids as well as abundant tortoise shell sand bones (Plug, 1981; Feyfant, 2019). The presence of several perforated beads bearing ochre residues 
and made from giant snail shells (Achatina sp.), ostrich eggshells and marine shells (Nassarius kraussianus) should be noted (Dayet et al., 2017). Finally, the LSA sequence is characterised by exceptionally well-preserved botanical remains such as seeds (cf. Sclerocarya birrea), phytoliths, charcoals and some remarkable fragments of unburnt wood, leaves, and grasses. The rich organic material preserved at BRS offers the opportunity to propose multi-proxy palaeoenvironmental reconstructions for the region, where only limited past climate records are available, especially for the late Pleistocene-early Holocene transition (but see Scott, 1999; Abell and Plug, 2000).

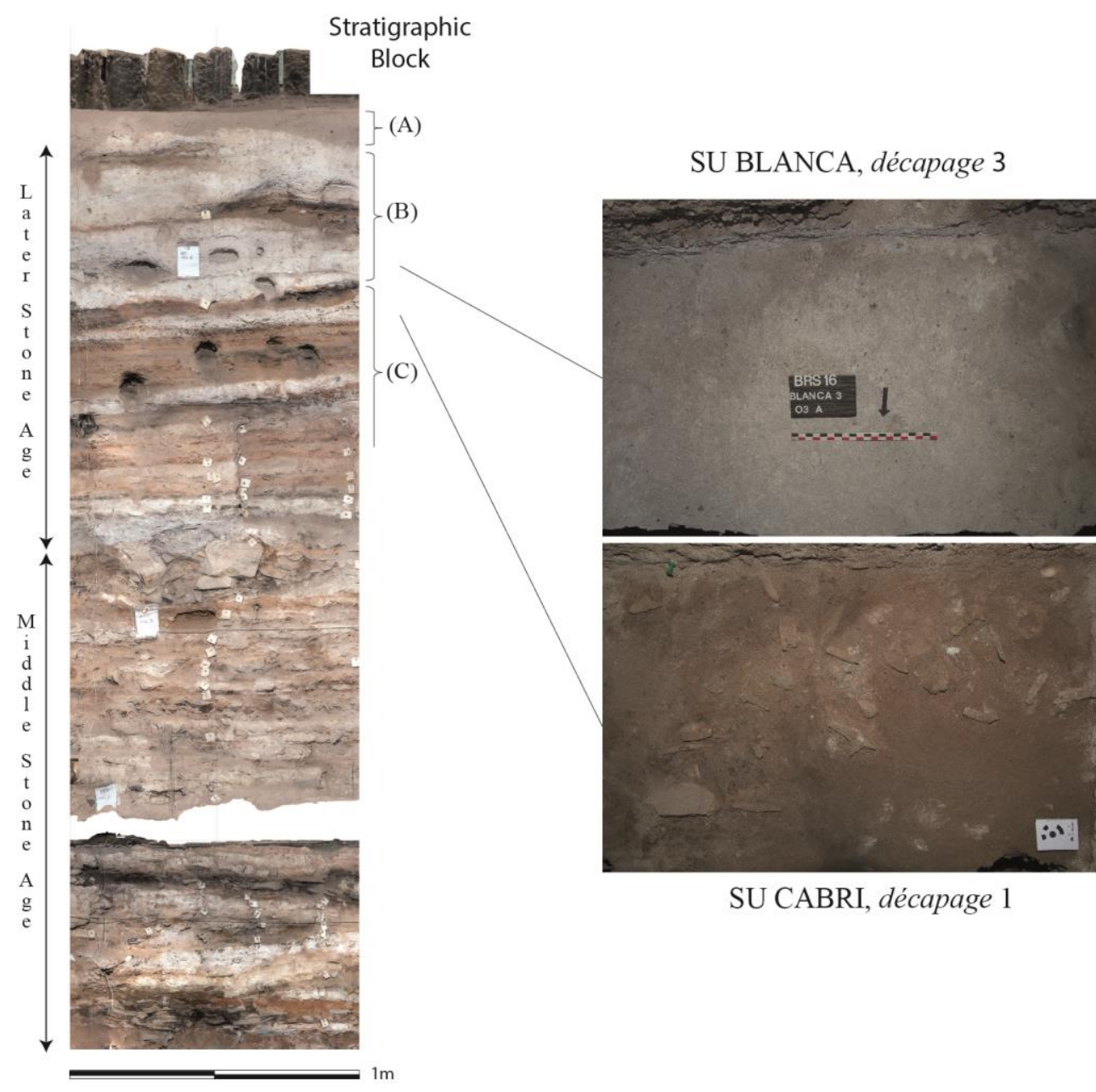

Figure 2: Upper South Profile of Bushman Rock Shelter (before excavation in 2014) with details on the SUs Blanca and Cabri. Ortho-photography by M. Haaland.

\section{Stratigraphic deposits and archaeological charcoal assemblage}

Initial observations identified the South profile as a preferred location for the new excavation of the LSA sequence at BRS. Stratigraphic units (SUs), referring to the smallest sedimentary event of the site formation, have been defined according to the soil description (colour, texture, 
and grain-size), as well as the composition and concentration in mineral and organic archaeological materials observed during the excavation (Figure 2). Each SU was excavated per décapage within the spatial grid, i.e. sub-square of $0.5 \times 0.5 \mathrm{~m}$ (but $0.4 \times 0.5 \mathrm{~m}$ for the LSA sequence part). A décapage represents a plane surface that is defined by the position of at least three artefacts (Porraz et al. 2018). A décapage is distinguished from a spit as it strictly follows the morphology and the natural slope of the deposit and since the thickness is not standardized but depends on the nature of the sediment and the density in archaeological material or in "remarkable" remains (e.g. beads). At BRS, the décapage do not exceeds 20 mm thick.

The sedimentary deposits of BRS are predominantly anthropogenic including generally thick whitish layers, alternating with usually thinner reddish layers and interspersed by brown and black lenses rich in botanical remains. The whitish- and reddish-coloured layers correspond to thin to thick sedimentary events that are loose or indurated with varying proportions of soil aggregates, ashes and scattered charred organic materials (Porraz et al., 2015). Preliminary micromorphological analyses suggest that the whitish-coloured layers are mostly composed of redeposited ashes with variable quantities of carbonized and humified plant materials. They could represent a long-term deposition resulting of mixing, and repeated activities most likely through anthropogenic processes, such as dumping or hearth rake-out (Chabal et al., 1999; Théry-Parisot et al., 2010a). The reddish-coloured layers present ubiquitous aggregates of silt and clay from an allochthonous source, likely a soil, from outside of the shelter (Miller and Mentzer, 2017; pers. comm.). At the site, both are the best-represented deposits in terms of spatial distribution.

While high variability in terms of sedimentation processes occurred for the different SUs at BRS, we assume that these reddish- and whitish-coloured units may represent several occupational phases and we interpret them as synthetic deposits according to the anthracological terminology (see section 1). They tend to extend laterally across the entire exposed profile (i.e., $4 \mathrm{~m}$ ) and they are characterized by some degree of sedimentary homogeneity throughout. As such, they are clearly distinct from localised organic lenses that are often basin-like and with a high concentration of botanical macro-remains such as charred seeds, charcoals and occasionally slightly charred twigs. These lenses can either be associated with plant processing and consumption areas, or with combustion feature areas (i.e. primary refuse such as remains of hearth-like structures) both derived from domestic fire activities. They may be interpreted 
as in situ occupation phases and may represent a range of chronological tempos from single or repeated short-time activities to long and persistent activity (Mentzer, 2014). Nevertheless, the temporality of a given SU will be reconsidered a posteriori of the anthracological results according to the number of taxa, their diversity and their ecological coherence.

Despite the quality of Eloff's excavation and the good preservation of the botanical remains, no systematic charcoal sorting occurred during the previous excavations and no anthracological study was carried out for the site. From the 2014 to 2018 campaigns, we carefully sorted the LSA fragments of wood charcoal using $3 \mathrm{~mm}$ mesh dry sieving from the bulk sediment excavated by décapage per sub-square $(0.4 \times 0.5 \mathrm{~m}$ for the LSA sequence) and per SU (ThéryParisot, 2015). A first diagnosis after sieving and sorting during excavation revealed high frequencies of charcoal fragments that could sometimes measure more than $20 \mathrm{~mm}$ in length.

\section{Material and methods}

\section{1. Selection of the stratigraphic units for the representativeness test}

To investigate the adequate sub-sampling approach and to verify the reproducibility of the method, it is important to assess the influence of the different types of sedimentary deposits on the charcoal spectra in terms of fragmentation, frequency and taxa richness. Two levels of analysis were conducted for this study. Firstly, we systematically counted charcoal fragments in 94 décapages from various SUs from the top of the LSA sequence (see Appendix A for detailed SUs list and data measurements). Secondly, we performed the taxonomic identifications on two SUs characteristics of the two types of synthetic deposits that are best represented at the site, i.e. the whitish and reddish layers. We excluded lenses from this study because the nature of charcoal accumulation must be known. The species diversity should be interpreted on a caseby-case basis and the accumulation process should be supported by further micromorphological analysis and archaeological studies. Therefore, the following SUs were analysed in one sub-square for each size-classes: SU Blanca and SU Cabri. Blanca is a thick, whitish, ashy-layer characterised by different concentrations and sizes of charcoal and seed fragments within the SU. It comprises few lithic and faunal artefacts associated with the Oakhurst techno-complex, dated to ca. $11 \mathrm{ka}$ cal BP. Because of the exploratory nature of this study and the thickness of SU Blanca, among the six décapages that composed the unit in the selected sub-square, we analysed charcoals from décapages 2, 4 and 6 only. Cabri is the SU 
directly underneath Blanca and it is defined as a ca. $2 \mathrm{~cm}$ thin pinkish to brownish soft layer. It is rich in faunal remains and lithic fragments in quartz also attributed to the Oakhurst phase and dated to $\mathrm{ca}$. $11.3 \mathrm{ka}$ cal BP. From the field observation Cabri does not appear particularly rich in botanical remains including charcoals, therefore, both décapages 1 and 2 that composed the SU were analysed.

\section{2. Estimation process of charcoal fragment count}

In this study, to assess the different charcoal abundances throughout the LSA sequence, we randomly selected the charcoal fragments from 94 décapages indifferent SUs and grid subsquares to be counted (see Appendix A for detailed SUs list and data measurements). Given the large range of size and the abundance of fragments in some of the smallest excavation units, i.e. décapage by SU and by sub-square, it initially proved practical to separate them into five size-classes: [3; 5[ mm, [5; 10[ mm, [10; 15[ mm, [15; 20[ mm and $\geq 20 \mathrm{~mm}$, as was applied at Sibudu Cave (Allott, 2004, 2005, 2006, Figure 3). We then measured the weight and the volume for all selected décapages. Due to the irregular sizes and shapes of charcoals remains and the unavoidable inclusion of air pockets in the beaker used, the volume measurement is inaccurate for larger fragments. Therefore, the weight was measured for each size-class but the volume could only be measured for the two smallest size-classes $[3 ; 5[\mathrm{~mm}$ and $[5 ; 10[\mathrm{~mm}$. As the volume of air pockets depends mainly on type and size of the container, the same graduated beakers were used to measure the two respective size-classes. 


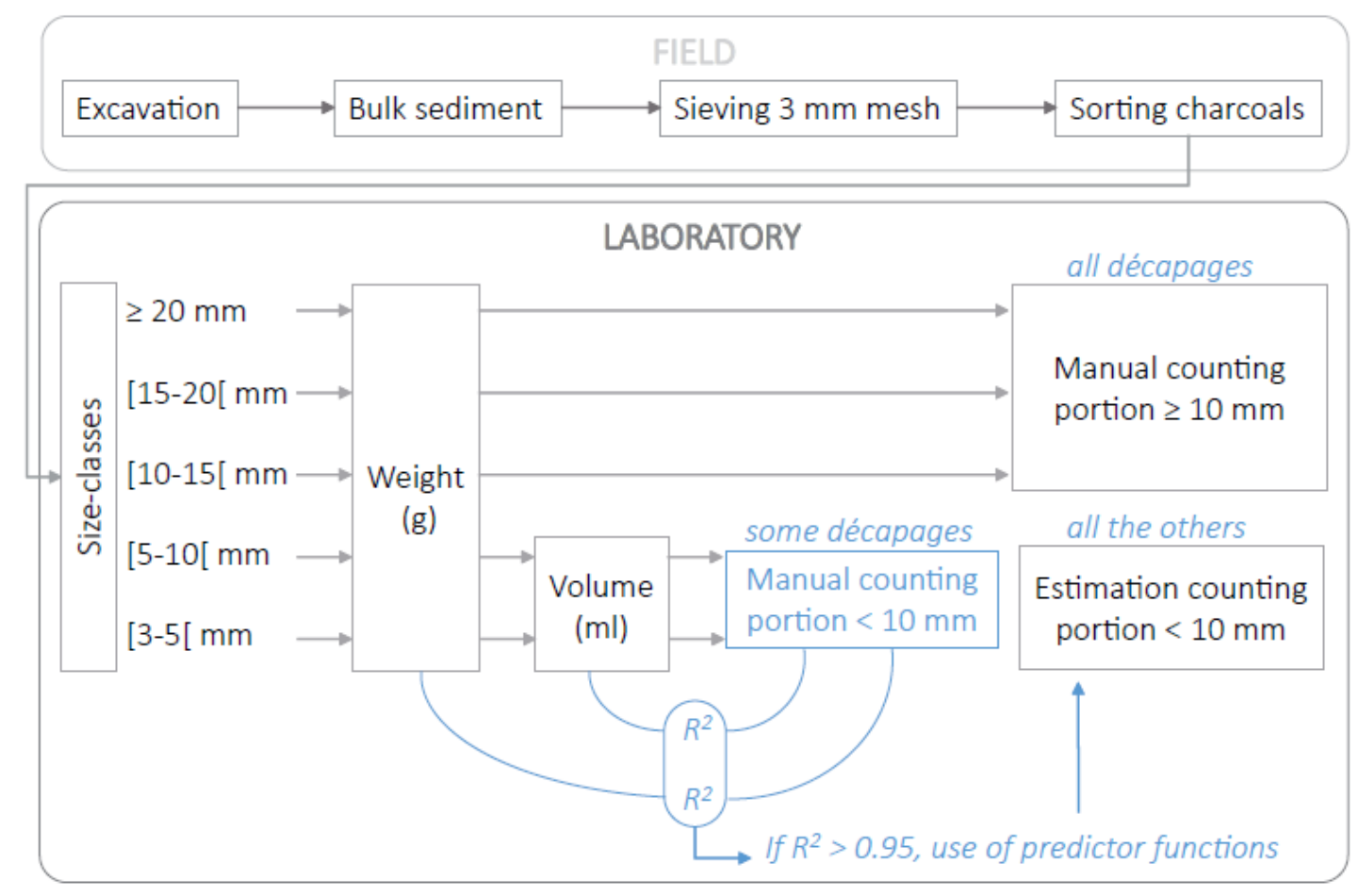

Figure 3: Flowchart of charcoal counting estimation for $<10 \mathrm{~mm}$ size-ranges with the use of function of correlation. $R^{2}=$ coefficient of correlation.

We counted manually the fragments from the three size-classes $\geq 10 \mathrm{~mm}$ for all the selected décapages. Since some small size-classes were abundant and the counting of each of them was time-consuming, we used an estimation count method based on the volume and weight for fragments $<10 \mathrm{~mm}$ (Figure 3). Firstly, we manually counted the fragments with size-range of [5; 10[ $\mathrm{mm}$ from 91 décapages and with size-range of [3; 5[ $\mathrm{mm}$ from 46 décapages in diverse SUs with variable abundance and various sedimentary nature of deposit (Appendix A). The choice of a lower number of counted décapages from the [3; 5[ $\mathrm{mm}$ range can be explained by the higher number of fragments for which the manual counting was particularly timeconsuming (up to 921 fragments for the most abundant, Appendix A). Secondly, the number of charcoals fragments per volume and per weight of these décapages was plotted for each sizeclass. Finally, the best approximate linear trend curves were drawn to build predictor functions and their respective coefficients of correlation $\mathrm{R}^{2}$ were compared. The function of correlation between the frequencies of charcoal fragments per décapage and both weight and volume is close to a polynomial function of type: $y=a x^{2}+b x$. We observed a highly significant correlation between the number of fragments and the weight of a given décapage sample with 
coefficients of correlation $R^{2}$ of 0.9945 for the [3; 5[ $\mathrm{mm}$ range and of 0.9584 for the $[5 ; 10$ [ $\mathrm{mm}$ range (Figure 4a). A slightly lower correlation, but still with very high significance, was observed between the number of fragments and the volume of a given sample with coefficients of correlation $\mathrm{R}^{2}$ of 0.9901 for the $[3 ; 5[\mathrm{~mm}$ range and of 0.9574 for the [5; 10[ $\mathrm{mm}$ range (Figure 4b). A greater difference in wood density and proportion of air pockets included in the beaker can explain the slightly lower correlation of the $[5 ; 10[\mathrm{~mm}$ range. The predictor function based on volume or weight can be used to quickly estimate the number of small fragments with accuracy in order to assess the abundance of charcoal fragments of the two small portions from the remaining décapages.

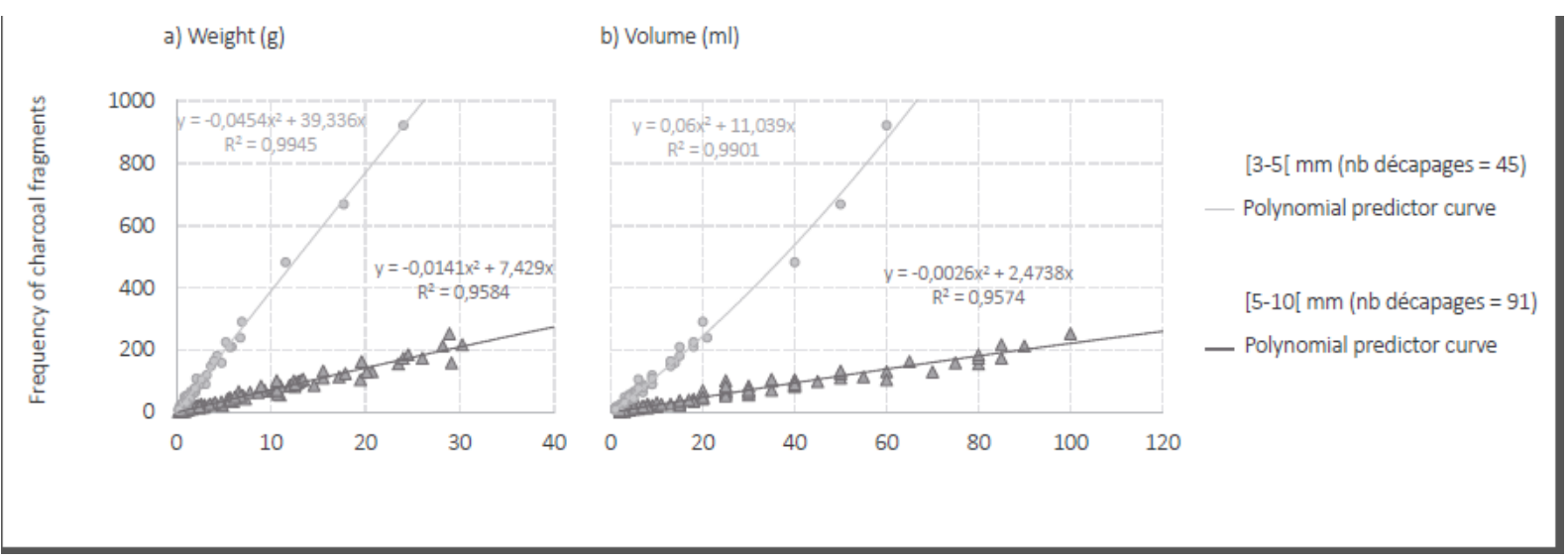

Figure 4: Frequencies of charcoal fragments manually counted against weight in grams (a) and against volume in millilitres (b). Polynomial predictor function and coefficient of correlation are mentioned above the trend curves in solid and dashed line.

\section{3. Anthracological analysis}

For the identification analysis of SUs Blanca and Cabri, each charcoal fragment was either manually broken or split with the help of a blade according to the required three planes for anatomical studies of wood: transverse, longitudinal tangential and longitudinal radial (Leney and Casteel, 1975). Anatomical characters were observed using a reflected light microscope with bright and dark fields at magnifications of 50x, 100x, 200x, 500x and occasionally 1000x for particular tiny anatomical wood features. The anatomical characters were recorded following the description of the IAWA Committee (Wheeler et al., 1989). For taxonomic identifications, they were compared with published anatomical wood atlases (Kromhout, 1975; Tusenius, 1986; Neumann et al., 2001; Eichhorn, 2002), the online database InsideWood (InsideWood, 2004-onwards; Wheeler, 2011), as well as with the modern reference collections available at the University of the Witwatersrand. These collections were started by Wadley and 
collaborators currently include more than 500 different taxa from diverse vegetation-types and climatic regimes of southern Africa (e.g. Wadley et al., 1992; Esterhuysen, 1996; Allott, 2006; Chikumbirike, 2014; Lennox, 2016; Lennox and Bamford, 2017, and unpublished collections including new modern specimens recently collected by the authors in the vicinity of BRS). Charcoal-type identification process follows the methodology described by Höhn and colleagues for the woody species-rich environment in Cameroon (Höhn, 2011; Höhn and Neumann, 2018). The taxonomic level attribution is mostly determined to the family and genus level followed by "sp.". Species attribution is only possible for monospecific genera or when a single species is present in the modern local vegetation and is generally preceded by "cf." meaning it is close to a given species. Charcoal-type concept is defined for current indeterminate taxa and a type may represent one or several species. Finally, fragments with poor preservation and/or with anatomical characters not discernible enough are classified as unidentifiable. The identification level is closely dependant on taphonomical preservation, the size of the fragment and the taxa available in reference collections. In the framework of the study of BRS charcoals, the identification process is still in progress, and taxa level identification could evolve as the work progresses. For this reason, the analysis of each sample proceeds from the largest fragments to the smaller ones. Large fragments provide a better image of the complete anatomical wood features, sometimes from heartwood to sapwood when preserved, and can later help to identify the small fragments. Nonetheless, we systematically analysed fragments from each size-classes to avoid any sample bias. The ecological meaning of identified charcoal-types is not the purpose of the present work and will be discussed in a future paper with more samples and SUs analysed.

We plotted the saturation curves alongside the taxonomic charcoal-type identifications for each décapage in order to discuss the richness and the representativeness of the total assemblage. These curves were obtained by plotting the taxa frequency against the number of analysed fragments in a given sample. We also produced Gini-Lorenz concentration curves to provide the woody plant diversity index of the sample (Chabal, 1997; Scheel-Ybert, 2002) by plotting the cumulative relative frequencies against the species rank percentages. The anthracology diagrams were plotted in relative frequency and in concentration (frequency related to the same percentage of volume of sediment) for each décapages in SUs Blanca and Cabri with the proportion of represented size-classes. Finally, we calculated the beta diversity $\beta$ 
- number of taxa that differ between samples or difference in taxa richness (Whittaker, 1972) between décapages to estimate the homogeneity pattern of a given SU.

\section{Results}

Figure 5 presents the differential abundance of charcoal fragments of the selected 94 décapages with the size-classes $[3 ; 5[$ and $[5 ; 10[\mathrm{~mm}$ estimated with the polynomial functions based on weight. These two smallest size-classes are the best represented portions but fragments $\geq 10 \mathrm{~mm}$ are not preserved in all décapages (Figure 5). A large variability in total charcoal frequencies is observed between décapages within a given SU from a minimum of 13 fragments (Betty P3A 6) to a maximum of 1794 fragments (Blanca P3D 7, Figure 5a, Appendix A). However, once the abundance is express in percentage, a lower amplitude of the variability is observed in a given size-class between décapages and size fragments seem to be spread according to a Poisson distribution (Figure 5b). Except for three décapages (i.e. Canta P3D 3, Canta N3D 2 and Cabu N3D 2), the smaller the size-classes are, the higher the charcoal abundance is. 


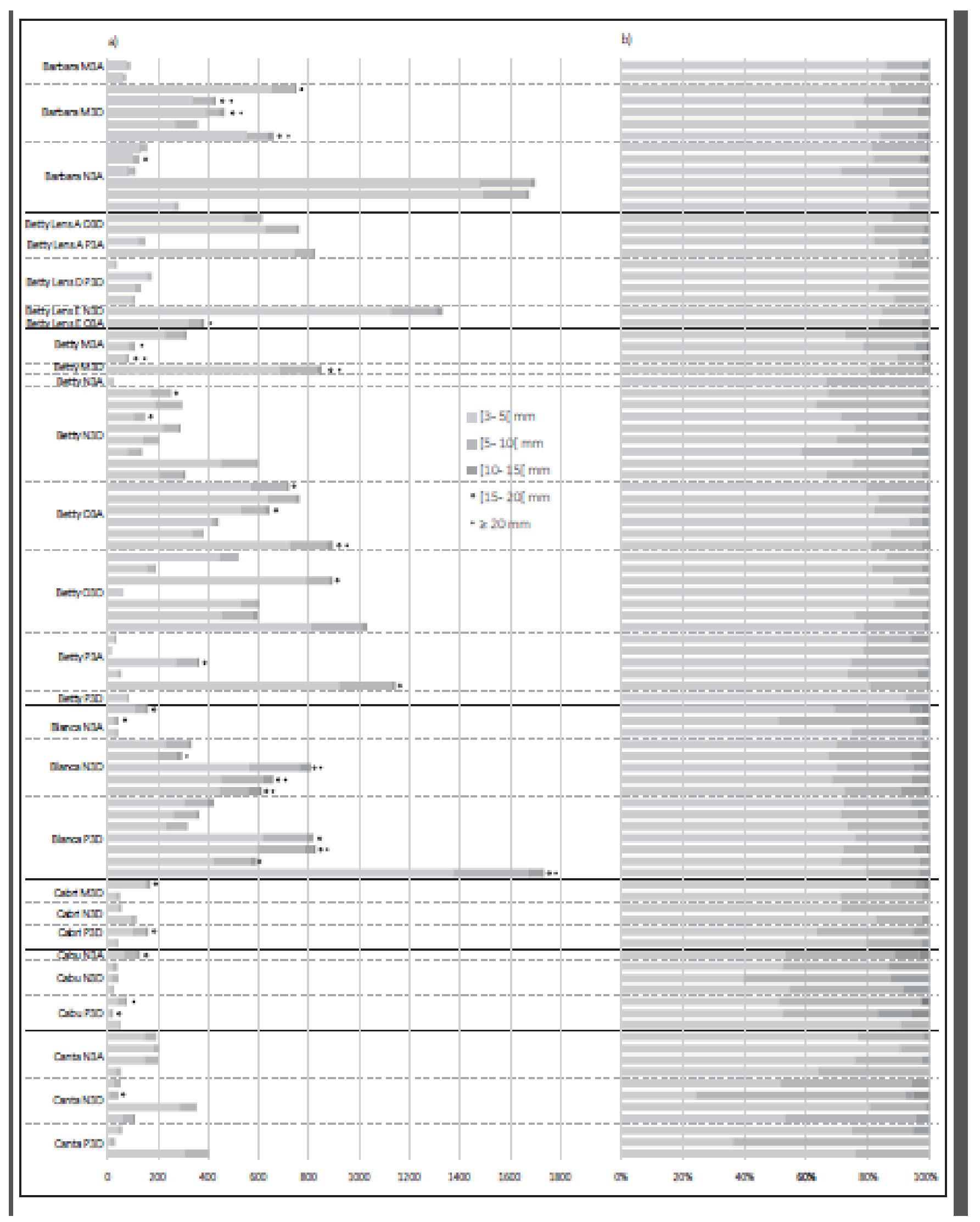

Figure 5: Charcoal abundance per SU per sub-square and per décapage (e.g. BlancaN3A: SU Blanca, sub-square N3A) and their distribution per size-classes. Fragment numbers from sizeclasses [3; 5 [ and $[5 ; 10[\mathrm{~mm}$ are estimated with respective polynomial predictor function based 
on charcoal weight. a) Charcoal abundance per décapage, b) Charcoal abundance related to the same percentage of volume. Hollow circle: presence of at least one fragment from $[15 ; 20[\mathrm{~mm}$. Solid circle : presence of at least one fragment $\geq 20 \mathrm{~mm}$ (see Appendix A for the details of the selected décapages and number of fragments).

For the analysis of SU Blanca, 169, 134 and 176 charcoal fragments were identified and 13, 14 and 12 different charcoal-types were respectively recognised in the décapages 2, 4 and 6 . Once grouped as a single assemblage, the total increases to 479 identified charcoal fragments distributed in 20 different charcoal-types whose percentage of relative frequencies are illustrated as an anthracology diagram in Figure 6a. A first observation is that in terms of frequencies the same six dominant charcoal-types are recognised in the three décapages of Blanca. A second observation is that the same dominant charcoal-types are distributed in at least three different size-classes from the smallest. Brachylaena sp. and Acacia sp. are the only charcoal-types that are distributed from $<5$ to $\geq 20 \mathrm{~mm}$ ranges. Since the fragment identification proceeded from the largest to the smallest fragments (see 4.3 section), the number of analysed fragments from [3; 5[ $\mathrm{mm}$ is limited and may misrepresent the real proportion of the charcoal-types in this size range. Therefore, when excluding the smallest sizeclass, the higher the relative frequencies of charcoal-types are, (1) the better represented the fragments into the five size-classes are, and (2) the higher the probability that they follow a Poisson distribution is. The 14 other charcoal-types have relative frequencies less than $10 \%$ and are never identified in the all three décapages. Indeed, these "rare" charcoal-types are more scattered between the three décapages and are never larger than $10 \mathrm{~mm}$. The identified "rare" charcoal-types are spread along the different analysed décapages and lead to a high beta diversity (> 55\% of difference in taxa richness between décapages). This induce taxa heterogeneity along the SU Blanca (Table 1). However, in terms of relative frequencies, around $90 \%$ of the total identified fragments are represented by the same six charcoal-types, which reflects a certain homogeneity that is summarised in the Blanca total grouping where the three décapages were analysed as a single sample. Finally, while the total concentration of charcoal fragments is higher in décapage 2 of Blanca $(84,5 / 1)$, larger fragments are present in the underlying décapages with much lower concentration (respectively 44,7/I and 14,7/I, Figure 6a). 


\begin{tabular}{|rrrrrrrr}
\hline & Blanca 2 & Blanca 4 & Blanca 6 & Cabri 1 & Cabri 2 & Blanca total & Cabritotal \\
Blanca 2 & $/$ & $11 / 20(55 \%)$ & $12 / 20(60 \%)$ & $6 / 11(55 \%)$ & $3 / 11(27 \%)$ & $/$ & $/$ \\
Blanca 4 & $/$ & $/$ & $12 / 20(60 \%)$ & $4 / 11(36 \%)$ & $4 / 11(36 \%)$ & $/$ & $/$ \\
Blanca 6 & $/$ & $/$ & $/$ & $7 / 11(64 \%)$ & $5 / 11(45 \%)$ & $/$ & $/$ \\
Cabri 1 & $/$ & $/$ & $/$ & $/$ & $8 / 13(62 \%)$ & $/$ & $/$ \\
Cabri 2 & $/$ & $/$ & $/$ & $/$ & $/$ & $/$ & $/$ \\
Blanca total & $/$ & $/$ & $/$ & $/$ & $/$ & $/$ & $/$ \\
Cabritotal & $/$ & $/$ & $/$ & $/$ & $/ 52 \%)$
\end{tabular}

Table 1: Beta diversity between all analysed décapages from SUs Blanca and Cabri and between Blanca total and Cabri total. The ratio of taxa differences per total taxa is followed by the beta diversity in percentage.

SU Cabri is composed of two décapages and 44 and 68 charcoal fragments were identified with 7 and 11 different charcoal-types recognised in the décapages 1 and 2, respectively. We analysed all the charcoal pieces in décapage 1 and two thirds of the sample in décapage 2, both from the largest to the smallest fragments (see 4.3 section). Once grouped as a single assemblage, the total increases to 112 identified charcoal fragments distributed in 13 different charcoal-types. The anthracology diagram in Figure $6 \mathrm{~b}$ illustrates the percentages of relative frequencies. The charcoal-type Acacia sp. is abundant in décapage 1 with ca. $80 \%$ of the total identified fragments. Acacia sp.is still the dominant charcoal-type recognised in décapage 2 to a lesser extent (ca. 40\%) and, with four other dominant charcoal-types, they reach ca. $80 \%$ of the total identified fragments. However, at this stage of the study caution should be exercised as charcoal-types could represent more than one species, particularly for Acacia sp. where more than 70 species occur in southern Africa and at least 19 species occur around BRS (Smit, 2008). No fragments are larger than $10 \mathrm{~mm}$ and only Acacia sp. and cf. Colophospermum mopane have fragments in the $[5 ; 10[\mathrm{~mm}$ size-class. Based on the small sample size of analysed fragments, we could not observe any fragment distribution pattern and the high beta diversity (62\% of difference in taxa richness) between décapage 1 and 2 explains the apparent heterogeneity in charcoal-types represented along the SU Cabri (Table 1). The total charcoal fragment concentrations are likely the same between the two décapages and thus do not distort the proportions of charcoal-types (Figure 6b). 


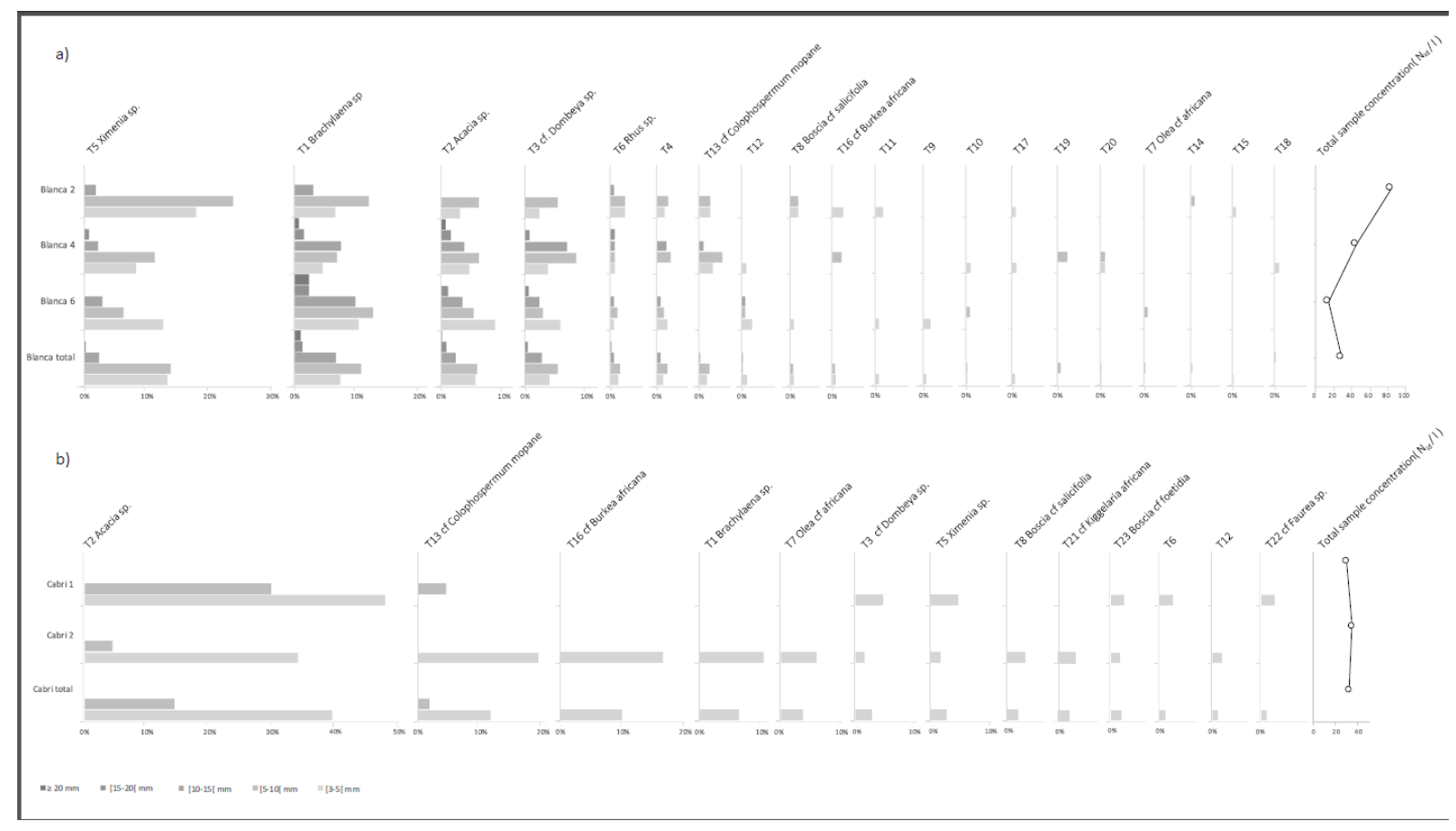

Figure 6: Anthracological diagrams of charcoal fragment frequencies in percentage and the charcoal concentration of the analysed samples in identified fragments per sediment litre $(\mathrm{Nid} / \mathrm{L})$. a) Frequencies of the analysed décapages of SU Blanca and of Blanca total as the sum of the analysed décapages. b) Frequencies of the analysed décapages of SU Cabri and of Cabri total as the sum of the analysed décapages. "T-number" refers to an identified charcoal-type and is followed by taxonomical attribution when determined. All histograms have the same scale percentage.

Décapages from SUs Blanca and Cabri present different patterns of fragmentation and of distribution (Figure 6). The total charcoal fragment concentration of Blanca décapages vary from very low (14,7/l in décapage 6$)$ to high (84,5/l in décapage 2$)$. Nonetheless, once grouped as a single sample, the total charcoal concentration is diluted in Blanca total $(28,2 / \mathrm{l})$ and becomes quite similar to the concentration of Cabri total (32/I). The beta diversity is about $52 \%$ between Blanca total and Cabri total based on the 23 different charcoal-types recognised but should be higher if only respective dominant charcoal-types are considered (Table 1).

\section{Discussion}

\section{1. Charcoal fragment frequency, concentration and distribution}

The use of interpolated function based on volume or weight to count efficiency and quickly samples with abundant charcoal fragments is sometimes used for botanical and microfaunal remains in archaeological and environmental studies (Chrzavzez, 2013; Théry-Parisot, pers. 
comm.). The polynomial functions reveal robust coefficients of correlation $R^{2}$ for both volume and weight methods. For the anthracological analysis of BRS, weighing of samples in the laboratory was deemed the most convenient method in terms of time investment and protocol. Nonetheless, the weight method requires an electronic scale and processing in the laboratory after excavation. The volume method needs only a graduated glass and is therefore suitable for a quick abundance estimation directly at the site during excavation. If the bucket volume/weight of excavated sediment is measured before sieving at the site, the measurement or estimation of charcoal volume, weight or frequency is also useful to estimate the concentration of charcoal fragments in a given sample. The taxa (or charcoal-type) concentration could provide further information regarding their relative spatial and temporal accumulation. It also allows inter- and intra-site comparisons and it could potentially provide information about the occupation patterns in terms of spatial management and site function. At BRS, the volume of sediments for each excavated décapage is systematically recorded, which allows us to estimate densities of archaeological material.

The particular conditions of accumulation of the archaeological deposits at BRS has enhanced the preservation of numerous macro charcoal remains with remarkable sizes, sometimes larger than $20 \mathrm{~mm}$. The abundance and range of sizes of charcoal fragments mean that they can easily be sorted into size-classes. We tested the relevance of using the five size-classes with an analysis of the abundance estimation, size-class distribution and fragmentation process of 94 décapages. Chabal (1991; 1997) demonstrated a Poisson distribution of the taxa fragmentations that has been formulated by the "single fragmentation law" hypothesis. This trend seems to be observed at the level of décapages' samples, independently of their relative charcoal fragment concentration or their taxa-type attribution (Figure 5). If some fragments did reach more than $20 \mathrm{~mm}$, the distribution pattern shows that only fragments from the two smallest size-classes [3; 5[ and [5; 10[ mm are statistically representative at BRS. Considering the time required for the sieving and analysis, it appears more convenient for the study of the entire sequence to group fragments $\geq 10 \mathrm{~mm}$ as a single size-class. Therefore, the recommended size-classes are [3; 5[, [5; 10[ and $\geq 10 \mathrm{~mm}$. This initial estimation of total frequencies of charcoal fragments from various décapages throughout the sequence provides an overview of the fragmentation patterns. 


\section{2. Sample representativeness}

The saturation curves (cumulated frequencies of analysed fragments against the frequencies of the cumulative identified charcoal-types) were plotted alongside the analysis for the three décapages of SU Blanca (Figure 7a, $\mathrm{c}$ and e). The saturation point was not reached for any of them, which likely results from the low number of identified fragments in each décapage (less than 200). When the three décapages are grouped as a single sample with a total of 479 charcoal fragments and a minimum of 20 different taxa, the saturation point is still not attained despite the larger sample size (Figure 7g). The number of identified fragments in the two décapages of Cabri is very low (respectively 57 and 111), which explains why no saturation points were reached (Figure $8 \mathrm{a}$ and b). Even when grouped, the total sample Cabri total remains too small (112 fragments analysed) to be interpreted (Figure 8e).

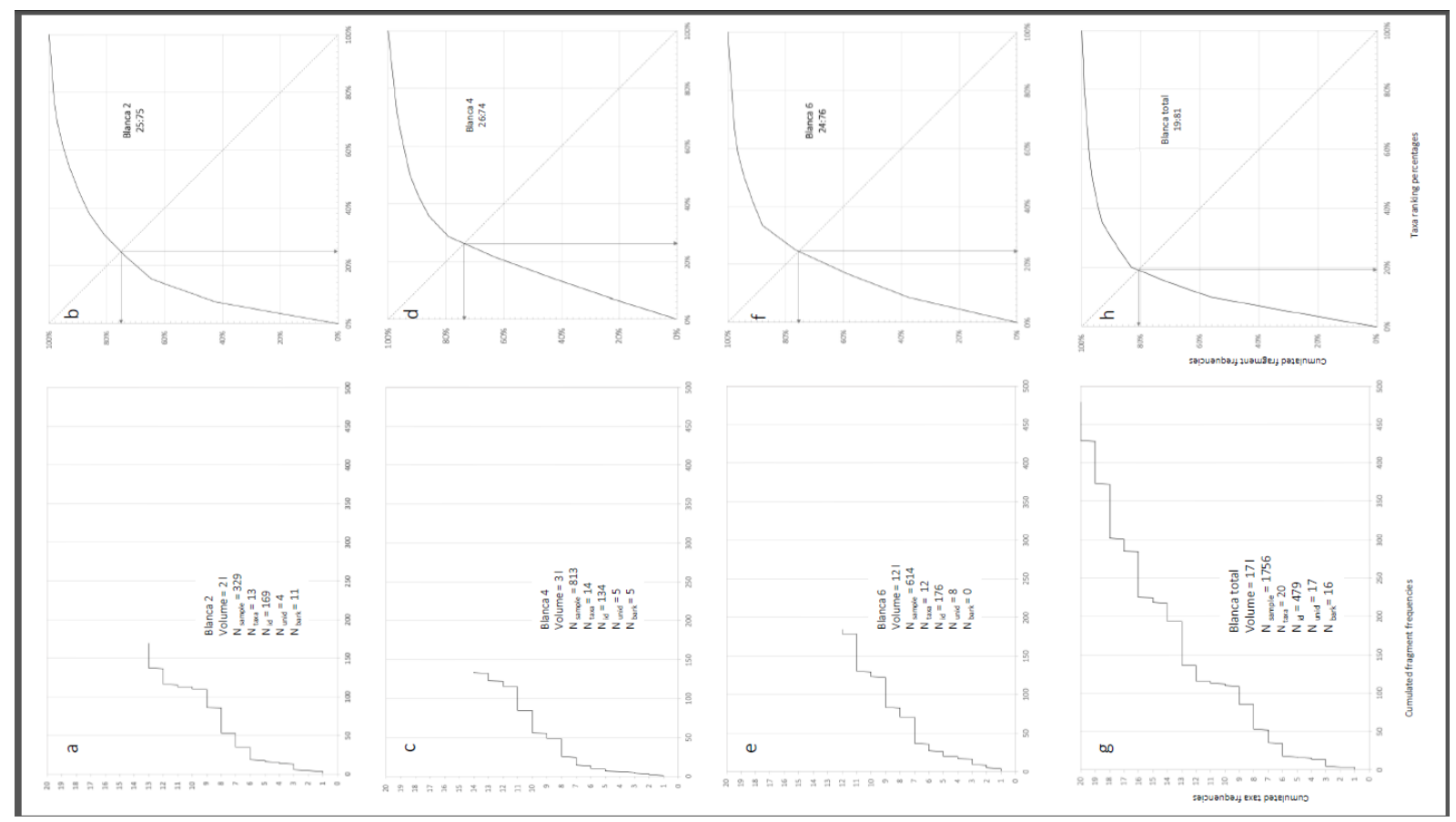

Figure 7

The unstabilised curves in Blanca and Cabri décapages were mainly inferred from the limited number of fragments that have been observed. Once the décapages of Blanca were grouped as a single sample, the unstabilised curve was less reliant on the sample size (479 fragments analysed) but better reflective of the charcoal-type richness in woody species-rich environments characterised by grassy and savanna woodland of southern Africa. It is often expected in species-rich environments that stabilisation of the frequency saturation curves is 
difficult to reach, for instance in tropical regions (Scheel-Ybert, 1998; 2002, Figure 9a). For this reason, we propose to visualise the saturation curves from Blanca total and Cabri total with cumulated charcoal-type frequencies (ordinate axis) in a logarithm scale (Figure 10). Indeed, the logarithm scale allows spacing of the abundant charcoal-types and bringing closer together the numerous "rare" charcoal-types. More importance is then placed on the dominant taxa and less importance on the "rare" taxa that disturb the quantitative interpretation (Figure 9b and 10b). The saturation curve from Blanca total is less steep and a threshold plateau is almost attained, showing that Blanca total presents a good sample size. This model of saturation curve plotting is useful to highlight trends that are hidden by the presence of many taxa with low frequencies. However, the Cabri total sample remains too small in frequency to reveal any threshold plateau. For thin SUs (ca. $<5 \mathrm{~cm}$ thick) with low concentration of charcoals (32/I analysed out of $48 /$ I from total excavated sediment) such as Cabri, the spatial unit of a subsquare $(40 \times 50 \mathrm{~cm})$ is too small. We therefore recommend the analysis of two sub-squares to increase both the surface and sample size in order to obtain reliable quantitative (frequency) and qualitative (taxa richness) results.

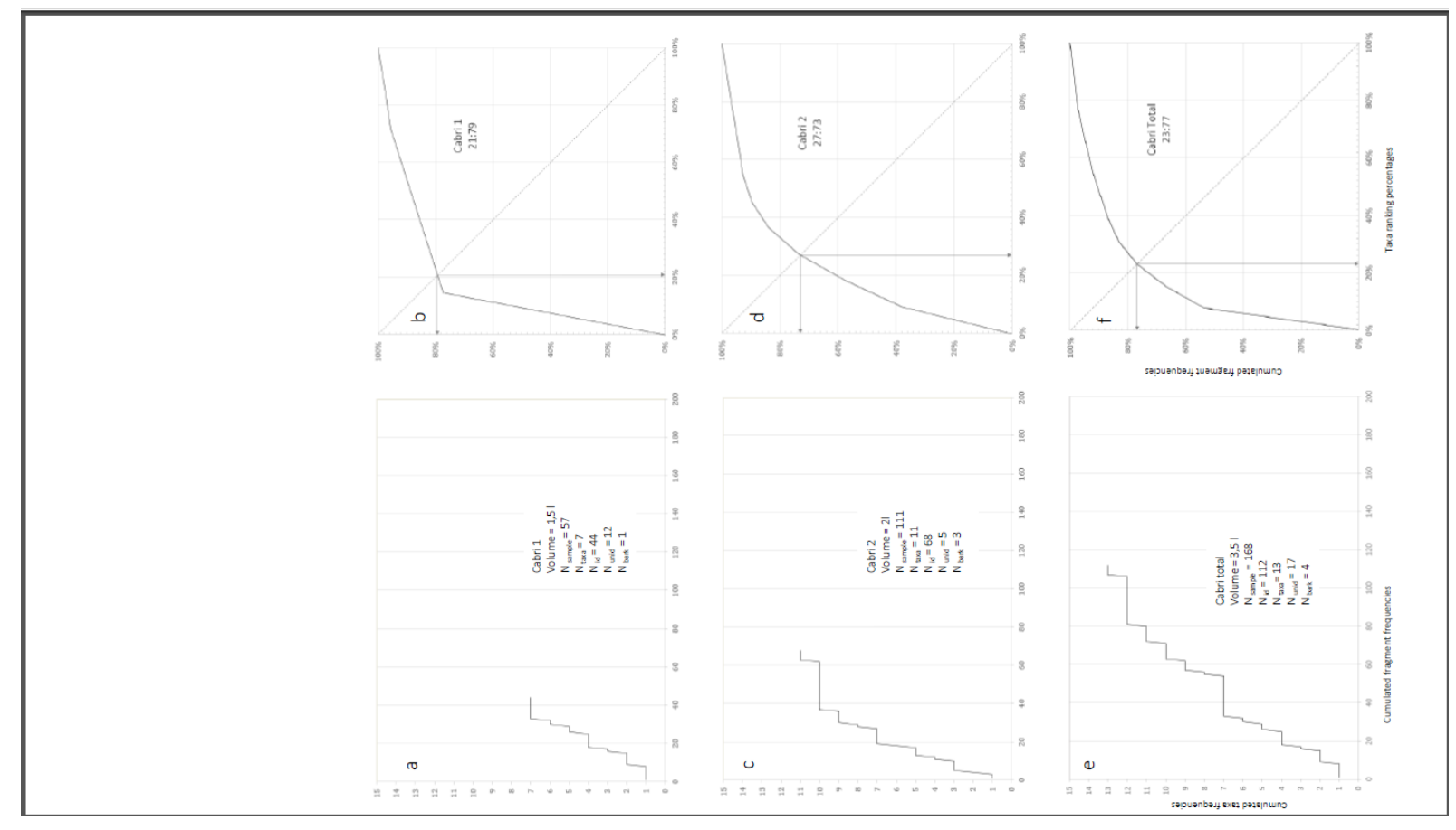

Figure 8 


\section{3. Ecological representativeness}

The Gini-Lorenz concentration curves from Blanca décapages are plotted in Figure $7 b, d, f$ with indices ranging from $26: 74$ ( $26 \%$ of the taxa richness represents $74 \%$ of the sample analysed) to 24:76 for the three décapages. These indices are considered as "normal" for rich and diverse taxa environments and are in accordance with reasonably well distributed taxa as observed in Figure 6a. The grouped décapages sample of Blanca total has an index of 19:81, which is close to an index for temperate environments and results from an increase of the "rare" charcoaltype richness identified with a lower distribution of these charcoal-types (Figure 8h).In contrast, the Gini-Lorenz concentration curves from Cabri décapages show a high index of 21:79 in décapage 1 resulting from a low taxa diversity due to a strong dominance of the charcoal-type Acacia spp. (80\%) (Figure 8b). The Gini-Lorenz index of 27:73 in décapage 2 is considered as "normal" for species-rich environments with a higher range of frequency (Figure 8d). The Cabri total assemblage presents a relatively high diversity with an index of 23:77 (Figure 8f). Nevertheless, these results should be regarded with caution due to the small total sample of 112.

The use of Gini-Lorenz concentrations has enabled the assessment of a reliable sample size in tropical region based on phytological studies of Brazilian vegetation-types (Scheel-Ybert, 1998; 2002). However, no Gini-Lorenz indices currently exist for modern southern African vegetation, which is characterized by a mix of vegetation-types with high species richness of woody plants (fynbos, forest, grassy and savanna woodland) and lower ones (semi-arid and desert where herbs and succulents dominate). The Gini-Lorenz concentration curves, which are visual and easy to use, could offer an interesting complementary approach, but the application of GiniLorenz indices based on Brazilian values must be used with extreme caution for southern African anthracology studies. More in-depth studies need to be carried out, in particular regarding the verification of whether there are ranges of values of this index that are more characteristic of southern African vegetal formations. 


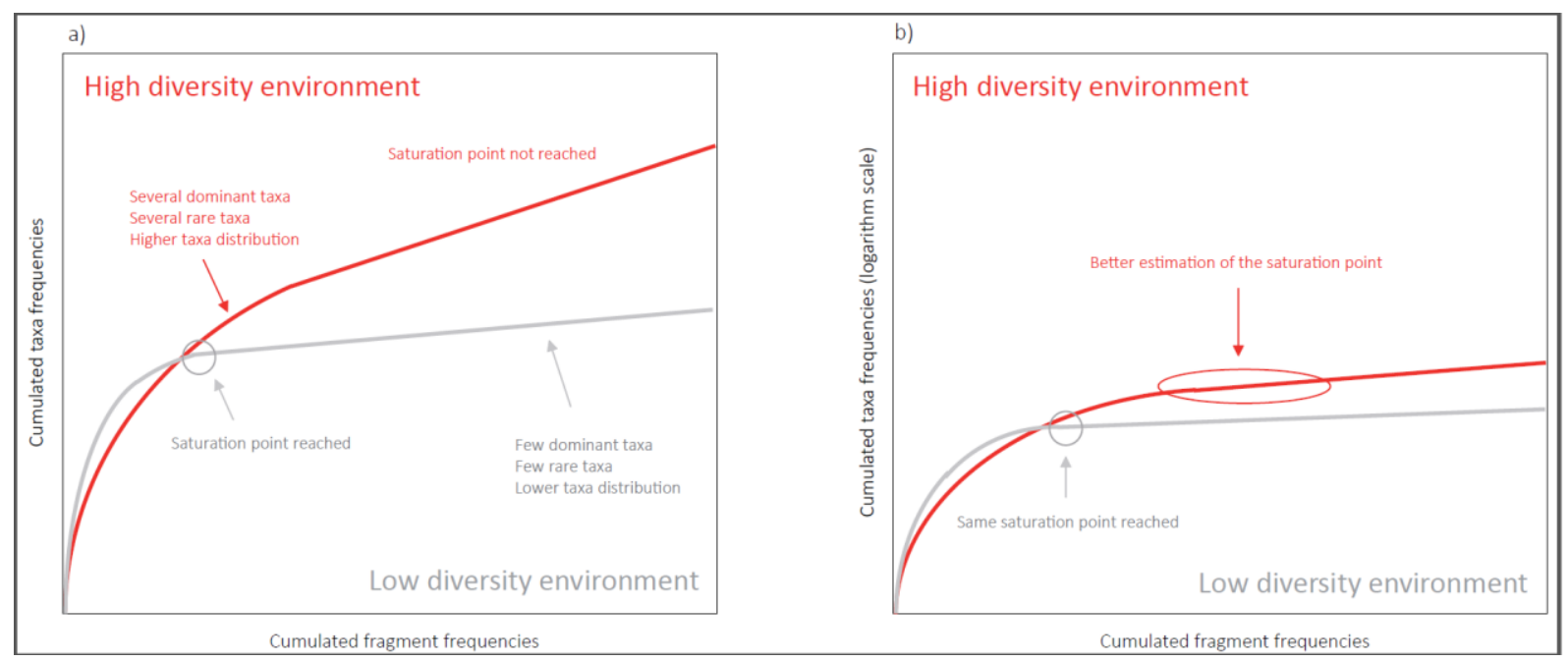

Figure 9

a)

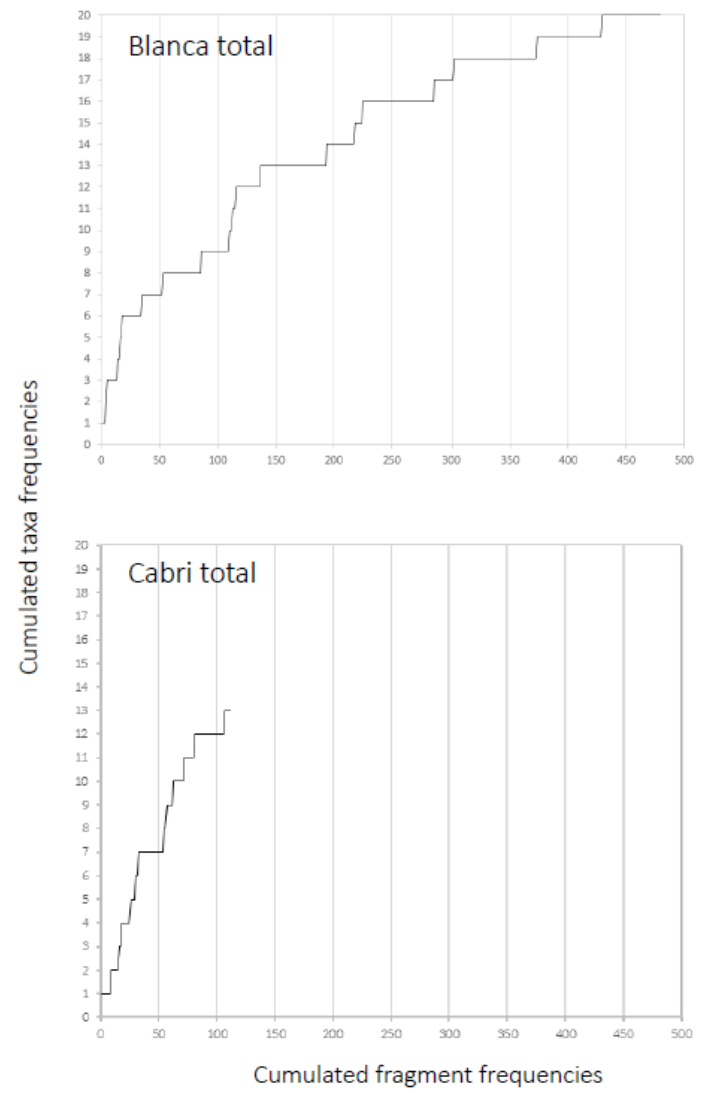

b)

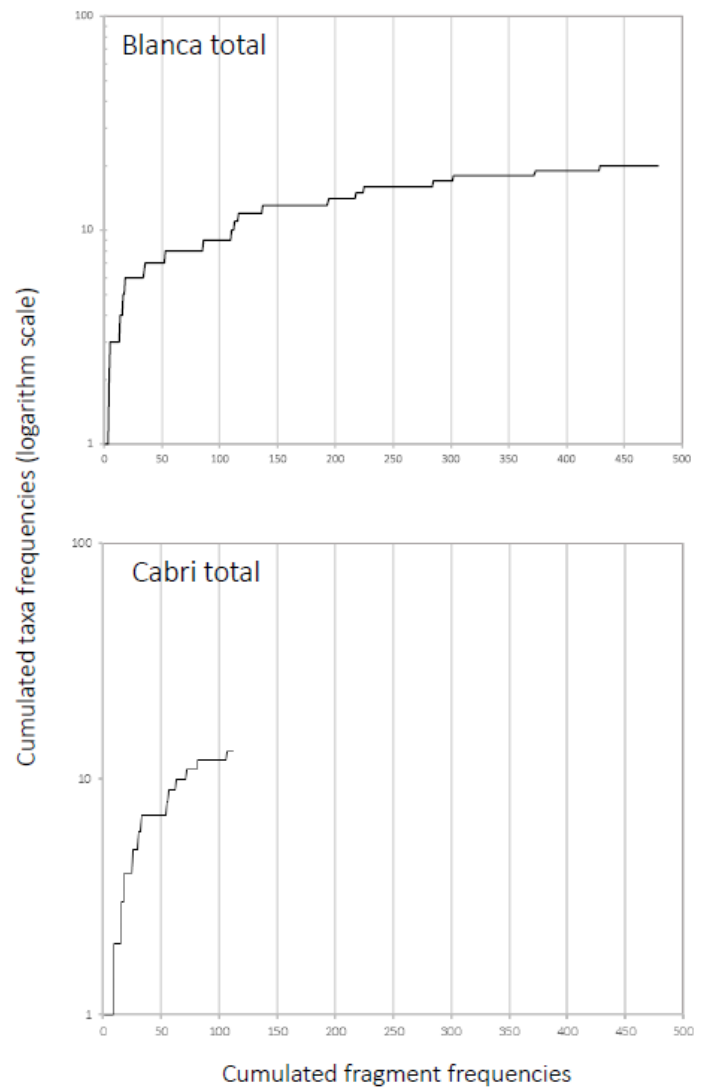

Figure 10 


\section{4. Resolution level of charcoal analysis}

\section{4. 1. Décapage versus stratigraphic unit}

The abundance of charcoal fragments should allow their analysis per décapage - i.e. the smallest excavation unit at the site. The analysis of two SUs resulting from different sedimentary processes reveals the need for a large size of identified charcoal fragments. An increase of identified fragments per décapage might allow (i) a better representation of the charcoal-type diversity; (ii) testing the Gini-Lorenz index reliability of the SU; and (iii) potentially stabilising the saturation curve. If it is possible to increase the number of identified fragments for Blanca décapages, a thin SU such as Cabri yields no statistically significant analysis per décapage. In addition, considering that a décapage follows the archaeological and geomorphological constraints imposed by the SU deposit, defining a décapage in terms of time resolution is complex.

Among the 23 different charcoal-types that we identified in SUs Blanca and Cabri, the dominant charcoal-types show different patterns in frequencies between the two SUs. In addition, while it is not significant for SU Cabri, the percentage frequencies of the dominant charcoal-types in the three décapages of SU Blanca are relatively homogeneous between the different décapages. Together, charcoal-type frequencies and the preliminary micromorphological observations ensure the relevance to analyse the LSA sequence of BRS using the SU as the level of resolution. However, in the case of thick SUs with high charcoal abundance like Blanca, the SU should be split into two samples, a top SU sample and a bottom SU sample to keep any potential information of resolution.

\section{4. 2. Size classes versus randomised analysis}

The analyses of the décapages of SUs Blanca and Cabri show that the fragmentation patterns are not homogeneous between charcoal-types and between décapages of any given SU and even between both SUs. For this reason, the analysis of a single size-class necessarily introduces a bias. One the one hand, the analysis of the largest fragments only decreases the taxa richness and diversity of the unit. On the other hand, the analysis of only the smallest fragments does not allow for the study of the fragmentation pattern of taxa throughout the sequence. To avoid any sampling bias during the analysis, randomised sampling has to be done in each size-class of 
a given SU. If the total sample size of the SU is less than 500 charcoal fragments, we recommend analysing all the pieces, in order to be representative of the SU. In the other cases, we suggest analysing a minimum of 500 fragments, in proportion of each size-class available for the given SU. The saturation curves (with logarithm scale of the cumulated taxa frequencies) and GiniLorenz curves should be plotted alongside the charcoal identification. If a saturation point is recognised, the analysis can stop; if not, it should not exceed the identification of 800 fragments.

\section{Conclusion}

This article proposes a review of the main anthracological principles and methods regarding their application to southern African contexts. Since the 1980's, archaeological projects in the region have increasingly integrated studies of charcoal recovered from the sites because they provide valuable palaeoecological and palaeoethnobotanical information. However, the question of the adequate sample size and of its representativeness of both the deposit and the environment have not been deeply explored and no normalized method has been developed for the whole region unlike what has been proposed for other regions (Chabal, 1992, 1994, Scheel-Ybert, 2002, Dotte-Sarout et al., 2015, Höhn and Neumann, 2018). We tested these methodological questions using the charcoal assemblage from two LSA stratigraphic units, which are characteristic of the main sedimentary processes at BRS.

We recommend the following methodological points for the specific anthracological study of the synthetic layers of the LSA sequence of BRS:

- Charcoal fragments from décapages should be sorted according to three size-classes: [3; 5[, [5; 10[ and $\geq 10 \mathrm{~mm}$ length;

- The analysis of the archaeological sequence should be performed at the stratigraphic unit level of resolution with some specificities:

- Thick SUs (ca. $>10 \mathrm{~cm}$ thick that are composed of at least 6 décapages and with high charcoal concentration) should be analyzed as two distinct samples, a top one grouping the upper décapages and a bottom one grouping the lower décapages; 
- The analysis of at least two subsquares is recommended for thin SUs (ca. $<5 \mathrm{~cm}$ thick) with low charcoals concentration ( $<20$ fragments / I), to increase sample size and taxa richness;

- To avoid any sampling bias during the analysis, randomized sampling has to be done in each size-class;

- The analysis of a minimum of 500 fragments per stratigraphic unit is recommended;

- The plot of the saturation curves with cumulated taxa in logarithm scale and Gini-Lorenz curves with caution of the indices interpretation is recommended alongside the identification to ensure the representativeness of the analysed sample regarding the total assemblage of the deposit. The saturation point cannot be reached systematically depending on the type of deposits but the use of the curves allows observing a trend in the taxonomic diversity.

Our work highlights the importance of systematic integration of the excavation techniques and the nature of the deposits based on both field observations and micromorphological analyses in order to elaborate a strict and adequate sampling strategy, from the field to the laboratory. Any sampling strategy should be adapted on a case-by-case basis and according to the specificities of the study site. We encourage further methodological studies to test and adapt the main principles of the discipline for the specific requirements of southern Africa.

\section{Acknowledgments}

The Bushman Rock Shelter project is funded by the French Ministry of Foreign affairs (excavation permit \#2475). We acknowledge the South African Heritage Resources Agency for providing the temporary export permit for the charcoal analysis conducted at the CEPAM at the University Côte d'Azur (permit ID2983). This article is part of a PhD project co-funded by the Martine Aublet Foundation of the Musée du Quai Branly Jacques Chirac. The support of the DST-NRF Centre of Excellence in Palaeosciences (CoE-Pal) towards this research is hereby acknowledged. Opinions expressed, and conclusions arrived at, are those of the authors and are not necessarily to be attributed to the CoE-Pal. We would like to acknowledge the Institut français en Afrique du Sud (IfAS - Recherche) for the mobility grant that allowed three of us (EP, MB and ITP) to sample modern woods for the reference collection and to visit the charcoal 
reference collections of the University of the Witwatersrand. The missions were financially supported by some Crédits Scientifiques Incitatifs from University Côte d'Azur lead by I. ThéryParisot (PRehistOire et BioarchEologie : Gestion des ressources végétales et paléoenvironnements des sociétés de chasseurs-cueilleurs d'Afrique du Sud, Bushman Rockshelter, Limpopo). We thank May Murungi for helping the authors with wood collection, as well as René Reddy and Kevin Balkwill for the identification of voucher specimens at the Moss Herbarium of the University of the Witwatersrand. We would like to thank Vanna Lisa Coli for her comments on data processing. This work was presented at the $7^{\text {th }}$ International Anthracological Meeting in Liverpool in September 2019. We want to thank Eleni Asouti for her invitation to contribute to the current special issue.

\section{References}

Abell, P.I. \& Plug, I. 2000. The Pleistocene/Holocene transition in South Africa: evidence for the younger Dryas event. Global and Planetary Change 26: 173-179

Allott, L.F., 2006. Palaeoenvironments of the Middle Stone Age at Sibudu Cave, KwaZulu-Natal, South Africa: An analysis of archaeological charcoal. Unpublished PhD thesis, University of the Witwatersrand, Johannesburg.

Asouti, E., Austin, P., 2005. Reconstructing woodland vegetation and its exploitation by past societies, based on the analysis and interpretation of archaeological wood charcoal macro-remains. Environmental Archaeology 10, 1-18. doi:10.1179/env.2005.10.1.1

Bamford, M.K., 2015. Macrobotanical remains from Wonderwerk Cave (Excavation 1), Oldowan to Late Pleistocene (2 Ma to 14 ka BP), South Africa. African Archaeological Review 32, 813-838.

Bamford, M.K., Neumann, F.H., Scott, L., 2016. Pollen, charcoal and plant macrofossil evidence of Neogene and Quaternary environments in southern Africa. In: Knight, J. and Grab, S.W. (Eds.). Quaternary Environmental Change in Southern Africa: Physical and Human Dimensions. Cambridge University Press, pp. 306-323.

Cartwright, C., Parkington, J., 1997. The wood charcoal assemblages from Elands Bay Cave, Southwestern Cape: principles, procedures and preliminary interpretation. The South African Archaeological Bulletin 52, 59. doi:10.2307/3888977

Cartwright, C.R., 2015. The principles, procedures and pitfalls in identifying archaeological and historical wood samples. Annals of Botany 116, 1-13. doi:10.1093/aob/mcv056

Chabal, L., 1991. L'Homme et l'évolution de la végétation méditerranéenne des âges des métaux à la période romaine; recherches anthracologiques théoriques, appliquées 
principalement à des sites du Bas-Languedoc. Thèse de doctorat, Université de Montpellier 2.

Chabal, L., 1992. La représentativité paléo-écologique des charbons de bois archéologiques issus du bois de feu. Bulletin de la société botanique de France. Actualités Botaniques $139,213-236$.

Chabal, L., 1997. Forêts et sociétés en Languedoc (néolithique final, antiquité tardive): l'anthracologie, méthode et paléoécologie. Editions de la Maison des sciences de I'homme.

Chabal, L., Fabre, L., Terral, J.F., Théry-Parisot, I., 1999. L'anthracologie. La botanique 43-104.

Chikumbirike, J., 2014. Archaeological and palaeoecological implications of charcoal assemblages dated to the Holocene from Great Zimbabwe and its hinterland. Unpublished PhD thesis, University of the Witwatersrand, Johannesburg.

Chrzavzez, J., 2013. Approche expérimentale de la conservation des charbons de bois dans les gisements paléolithiques: processus post-dépositionnels, fragmentation et représentativité des assemblages anthracologiques. Thèse de doctorat, Université Nice Sophia Antipolis.

Cowling, R.M., Cartwright, C.R., Parkington, J.E., Allsopp, J.C., 1999. Fossil wood charcoal assemblages from Elands Bay Cave, South Africa: implications for Late Quaternary vegetation and climates in the winter-rainfall fynbos biome. Journal of Biogeography 26, 367-378. doi:10.1046/j.1365-2699.1999.00275.x

Dayet, L., Erasmus, R., Val, A., Feyfant, L., Porraz, G., 2017. Beads, pigments and early Holocene ornamental traditions at Bushman Rock Shelter, South Africa. Journal of Archaeological Science: Reports 13, 635-651. doi:10.1016/j.jasrep.2017.05.015

Deacon, H.J., Scholtz, A., Daitz, L.D., 1983. Fossil charcoals as a source of palaeoecological information in the Fynbos region. Fynbos palaeoecology: a preliminary synthesis. South African National Scientific Programmes Report 174-82.

Deacon, H.J., Deacon, J., Scholtz, A., Thackeray, J.F., Brink, J.S., Vogel, J.C., 1984. Correlation of palaeoenvironmental data from the Late Pleistocene and Holocene deposits at Boomplaas Cave, southern Cape. Late Cainozoic palaeoclimates of the southern hemisphere 339-351.

Delhon, C., 2016. Les assemblages de charbons "concentrés" : une piste pour améliorer leur représentativité. (Charcoal concentrations: a new track for improving their reliability). Archéosciences 40, 7-15.

Dotte-Sarout, E., 2017. Evidence of forest management and arboriculture from wood charcoal data: an anthracological case study from two New Caledonia Kanak pre-colonial sites. Vegetation History and Archaeobotany 26, 195-211. doi:10.1007/s00334-016-0580-0 
Dotte-Sarout, E., Carah, X., Byrne, C., 2015. Not just carbon: assessment and prospects for the application of anthracology in Oceania. Archaeology in Oceania 50, 1-22. doi:10.1002/arco.5041

Dowson, T.A., 1988. Shifting vegetation zones in the Holocene and later Pleistocene: preliminary charcoal evidence from Jubilee Shelter, Magaliesberg, southern Transvaal. Palaeoecology of Africa and the Surrounding Islands 19, 233-239.

Dussol, L., Elliott, M., Théry-Parisot, I., 2017. Experimental anthracology: evaluating the role of combustion processes in the representivity of archaeological charcoal records in tropical forests, a case study from the Maya Lowlands. Journal of Archaeological Science: Reports 12, 480-490.

Eichhorn, B., 2002. Anthrakologische Untersuchungen zur Vegetationsgeschichte des Kaokolandes, Nordwest-Namibia. PhD-Thesis, University of Cologne.

Eichhorn, B., 2007. Use of firewood resources in a hyperarid environment: charcoal analysis from sites in the Skeleton Coast Park, Northern Namib Desert. In:Cappers, R.T.J., (Eds) Fields of Change: Progress in African Archaeobotany. Barkhuis. pp. 21-34.

Eloff, J.F., 1969. Bushman Rock Shelter, Eastern Transvaal: Excavations, 1967-8. The South African Archaeological Bulletin 24, 60-60.

Esterhuysen, A., 1996. Palaeoenvironmental reconstruction from Pleistocene to present: an analysis of charcoal from sites in the eastern Free State and Lesotho. Unpublished PhD thesis, University of the Witwatersrand, Johannesburg.

Esterhuysen, A., Mitchell, P., 1996. Palaeoenvironmental and archaeological implications of charcoal assemblages from Holocene sites in western Lesotho, southern Africa. Palaeoecology of Africa 24, 203-232.

February, E., 1992. Archaeological charcoals as indicators of vegetation change and human fuel choice in the late Holocene at Elands Bay, Western Cape Province, South Africa. Journal of Archaeological Science 19, 347-354. doi:10.1016/0305-4403(92)90021-T

Feyfant, L., 2019. L'exploitation de la faune par les chasseurs-collecteurs Later Stone Age à Bushman Rock Shelter (Limpopo, Afrique du Sud).In: Lesedi. Field notes \#21.

Figueiral, I., 1992. Méthodes en anthracologie: étude de sites du Bronze final et de l'âge du Fer du nord-ouest du Portugal. Bulletin de la Société Botanique de France. Actualités Botaniques 139, 191-204. doi:10.1080/01811789.1992.10827099

Figueiral, I., Mosbrugger, V., 2000. A review of charcoal analysis as a tool for assessing Quaternary and Tertiary environments: achievements and limits. Palaeogeography, Palaeoclimatology, Palaeoecology, Fire and the Palaeoenvironment 164, 397-407. doi:10.1016/S0031-0182(00)00195-4

Höhn, A., 2011. Analysis of Charcoal Finds. In: Oursi Hu-Beero. A Medieval House Complex in Burkina Faso, West Africa. pp. 141-150. 
Höhn, A., Neumann, K., 2018. Charcoal identification in a species-rich environment: The example of Dibamba, Cameroon. IAWA Journal 39, 87-S47. doi:10.1163/2294193220170195

InsideWood, 2004. . Published on the Internet. http://insidewood.lib.ncsu.edu/search [. URL https://insidewood.lib.ncsu.edu/citingus (accessed 6.19.20).

Kromhout, C.P., 1975. n Sleutel vir die mikroskopiese uitkenning van die vernaamste inheemse houtsoorte van Suid-Afrika. Bulletin, Dept. Of Forestry Bulletin 50: 124., South Africa 140-140.

Leney, L., Casteel, R.W., 1975. Simplified procedure for examining charcoal specimens for identification. Journal of Archaeological Science 2, 153-159. doi:10.1016/03054403(75)90035-7

Lennox, S.J., 2016. Woody taxa from charcoal in Sibudu's Middle Stone Age hearths. Unpublished PhD thesis, University of the Witwatersrand, Johannesburg.

Lennox, S.J., Bamford, M.K., 2017. Identifying Asteraceae, particularly Tarchonanthus parvicapitulatus, in archaeological charcoal from the Middle Stone Age. Quaternary International, Anthracology: Local to Global Significance of Charcoal Science - Part I 457, 155-171. doi:10.1016/j.quaint.2017.03.074

Lombard, M., Wadley, L., Deacon, J., Wurz, S., Parsons, I., Mohapi, M., Swart, J., Mitchell, P., 2012. South African and Lesotho stone Age sequence updated (I). The South African Archaeological Bulletin 67, 123-144.

Louw, A.W., 1969. Bushman Rock Shelter, Ohrigstad, Eastern Transvaal: A Preliminary Investigation, 1965. The South African Archaeological Bulletin 24, 39-51. doi:10.2307/3887660

Mentzer, S.M., 2014. Microarchaeological approaches to the identification and interpretation of combustion features in Prehistoric archaeological Sites. Journal of Archaeological Method and Theory 21, 616-668. doi:10.1007/s10816-012-9163-2

Miller, C.E., Mentzer, S.M., 2017. Preliminary report on micromorphological analyses of sediments from Bushman Rock shelter, South Africa (Rapport d'opération), in Porraz et al., 2017. Projet Bushman, Limpopo, Afrique du sud.

Mucina, L., Rutherford, M.C., 2006. The vegetation of South Africa, Lesotho and Swaziland. South African National Biodiversity Institute.

Mvimi, M., 2019. Reconstruction of environments and plant use in Holocene Southern Africa: study of macrobotanical remains from Late Stone Age sites of Toteng (Botswana), Leopard Cave and Geduld (Namibia) (PhD Thesis). Paris, Muséum national d'histoire naturelle. 
Neumann, K., 1999. Charcoal from West African Savanna Sites. In: Veen, M. van der (Ed.), The Exploitation of Plant Resources in Ancient Africa. Springer US, Boston, MA, pp. 205-219. doi:10.1007/978-1-4757-6730-8_17

Neumann, K., Schoch, W., Detienne, P., Schweingruber, F., 2001. Woods of the Sahara and the Sahel: an anatomical atlas $=$ Bois du Sahara et du Sahel $=$ Hölzer der Sahara und des Sahel. Haupt, Bern.

Parkington, J., Cartwright, C., Cowling, R.M., Baxter, A., Meadows, M., 2000. Palaeovegetation at the last glacial maximum in the western Cape, South Africa: wood charcoal and pollen evidence from Elands Bay Cave. South African Journal of Science 96, 543-546.

Plug, I., 1981. Some research results on the Late Pleistocene and Early Holocene deposits of Bushman Rock Shelter, Eastern Transvaal. The South African Archaeological Bulletin 36, 14-21. doi:10.2307/3888014

Porraz, G., Val, A., Dayet, L., De La Peña, P., Douze, K., Miller, C.E., Murungi, M.L., Tribolo, C., Schmid, V.C., Sievers, C., 2015. Bushman Rock Shelter (Limpopo, South Africa): A perspective from the edge of the Highveld. The South African Archaeological Bulletin 70, 166-179.

Porraz, G., Val, A., Tribolo, C., Mercier, N., de La Peña, P., Haaland, M. M., ... \& Schmid, V. C. 2018. The MIS5 Pietersburg at '28'bushman rock shelter, Limpopo province, South Africa. PloS one, 13(10), e0202853.

Prior, J., Price Williams, D., 1985. An investigation of climatic change in the Holocene epoch using archaeological charcoal from Swaziland, Southern Africa. Journal of Archaeological Science 12, 457-475. doi:10.1016/0305-4403(85)90005-6

Puech E., 2019. Gestion du bois et paléoenvironnements à la transition Pléistocène/Holocène dans le bassin sud du Limpopo. Les chasseurs-cueilleurs du Later Stone Age du site de Bushman Rock Shelter. In: Lesedi. Field notes \#21.

Scott L (1999) Vegetation history and climate in the Savanna biome South Africa since 190,000 ka: a comparison of pollen data from the Tswaing Crater (the Pretoria Saltpan) and Wonderkrater. Quat Int 57/58:215-223

Scheel-Ybert, R., 1998. Stabilité de l'écosysteme sur le littoral Sud-Est du Brésil à l'Holocène Supérieur (5500-1400 ansBP). Les pêcheurs-cueilleurs-chasseurs et le milieu végétal : apports de I'anthracologie (PhD Thesis). Ph. D. Thesis, USTL, Montpellier, France. 3 volumes.

Scheel-Ybert, R., 2002. Evaluation of sample reliability in extant and fossil assemblages. Bar International Series 1063, 9-16.

Scholtz, A., 1986. Palynological and palaeobotanical studies in the southern Cape. Unpublished PhD thesis, University of Stellenbosch, Stellenbosch. 
Siebert, S.J., Wyk, A.E. van, Bredenkamp, G.J., 2002. The physical environment and major vegetation types of Sekhukhuneland, South Africa. South African Journal of Botany 68, 127-142. doi:10.1016/S0254-6299(15)30412-9

Smit, N., 2008. Field guide to the acacias of South Africa. Briza, Arcadia.

Théry-Parisot, I., 2015. Charcoal analysis. Projet Bushman (Limpopo, République d’Afrique du Sud). Contribution au rapport de fouille programmée. (Technical Report). UCA CNRS.

Théry-Parisot, I., Chabal, L., Chrzavzez, J., 2010a. Anthracology and taphonomy, from wood gathering to charcoal analysis. A review of the taphonomic processes modifying charcoal assemblages, in archaeological contexts. Palaeogeography, Palaeoclimatology, Palaeoecology 291, 142-153. doi:10.1016/j.palaeo.2009.09.016

Théry-Parisot, I., Chabal, L., Ntinou, M., Bouby, L., Carré, A., 2010b. From wood to wood charcoal: an experimental approach to combustion. Du bois aux charbons de bois: approche expérimentale de la combustion. In: Théry-Parisot, I., Chabal, L., Costamagno (Eds.), S. (Eds.), Taphonomie de La Combustion Des Résidus Organiques et Des Structures de Combustion En Contexte Archéologique, Actes de La Table Ronde Internationale, 27-29 Mai 2008, Valbonne, Sophia-Antipolis, CEPAM, France. Presses universitaires du Midi.

Thuiller, W., Midgley, G.F., Rougeti, M., Cowling, R.M., 2006. Predicting patterns of plant species richness in megadiverse South Africa. Ecography 29, 733-744. doi:10.1111/j.0906-7590.2006.04674.x

Tusenius, M.L., 1986. The study of charcoal from some southern African archaeological contexts. Unpublished PhD Thesis, Stellenbosch University, Stellenbosch.

Tusenius, M.L., 1989. Charcoal analytical studies in the north-eastern Cape, South Africa. Goodwin Series 77-83.

Van Wyk, B., Smith, G., 2001. Regions of floristic endemism in Southern Africa: a review with emphasis on succulents. Umdaus Press, Hatfield, South Africa.

Vogelsang, R., Eichhorn, B., 2011. Under the Mopane Tree: Holocene Settlement in Northern Namibia.Vol 24. Heinrich Barth Institut e.V.

Vogelsang, R., Eichhorn, B., Richter, J., 2002. Holocene human occupation and vegetation history in northern Namibia. Holocene human occupation and vegetation history in northern Namibia. Erde, vol 133, 113-132.

Wadley, L., Jacobs, Z., 2006. Sibudu Cave : background to the excavations, stratigraphy and dating. Southern African Humanities 18, 1-26.

Wadley, L., Esterhuysen, A., Jeannerat, C., 1992. Vegetation changes in the eastern Orange Free State: The Holocene and later Pleistocene evidence from charcoal studies at Rose Cottage Cave. South African Journal of Science 88, 558-563. 
Wheeler, E.A., 2011. Inside Wood - A Web resource for hardwood anatomy. IAWA Journal 32, 199-211. doi:10.1163/22941932-90000051

Wheeler, E.A., Baas, P., Gasson, P.E., 1989. IAWA list of microscopic features for hardwood identification: with an appendix on non-anatomical information. National Herbarium of the Netherlands.

Whitau, R., Balme, J., O'Connor, S., Wood, R., 2017. Wood charcoal analysis at Riwi cave, Gooniyandi country, Western Australia. Quaternary International, Anthracology: Local to Global Significance of Charcoal Science - Part | 457, 140-154. doi:10.1016/j.quaint.2016.07.046

Whittaker, R.H., 1972. Evolution and measurement of species diversity. TAXON 21, 213-251. doi:10.2307/1218190

Will, M., El-Zaatari, S., Harvati, K., Conard, N.J., 2019. Human teeth from securely stratified Middle Stone Age contexts at Sibudu, South Africa. Archaeological and Anthropological Sciences 11, 3491-3501. doi:10.1007/s12520-018-00774-4 